\title{
Bark Thickness Equations for Mixed-Conifer Forest Type in Klamath and Sierra Nevada Mountains of California
}

\author{
Nickolas E. Zeibig-Kichas, Christopher W. Ardis, John-Pascal Berrill, and Joseph P. King \\ Department of Forestry and Wildland Resources, Humboldt State University, 1 Harpst St. Arcata, CA 95521, USA \\ Correspondence should be addressed to Nickolas E. Zeibig-Kichas; nek75@humboldt.edu
}

Received 10 July 2016; Revised 4 October 2016; Accepted 1 November 2016

Academic Editor: Mark Finney

Copyright (C) 2016 Nickolas E. Zeibig-Kichas et al. This is an open access article distributed under the Creative Commons Attribution License, which permits unrestricted use, distribution, and reproduction in any medium, provided the original work is properly cited.

\begin{abstract}
We studied bark thickness in the mixed-conifer forest type throughout California. Sampling included eight conifer species and covered latitude and elevation gradients. The thickness of tree bark at $1.37 \mathrm{~m}$ correlated with diameter at breast height (DBH) and varied among species. Trees exhibiting more rapid growth had slightly thinner bark for a given DBH. Variability in bark thickness obscured differences between sample locations. Model predictions for $50 \mathrm{~cm} \mathrm{DBH}$ trees of each species indicated that bark thickness was ranked Calocedrus decurrens $>$ Pinus jeffreyi $>$ Pinus lambertiana $>$ Abies concolor $>$ Pseudotsuga menziesii $>$ Abies magnifica $>$ Pinus monticola > Pinus contorta. We failed to find reasonable agreement between our bark thickness data and existing bark thickness regressions used in models predicting fire-induced mortality in the mixed-conifer forest type in California. The fire effects software systems generally underpredicted bark thickness for most species, which could lead to an overprediction in fire-caused tree mortality in California. A model for conifers in Oregon predicted that bark was $49 \%$ thinner in Abies concolor and 37\% thicker in Pseudotsuga menziesii than our samples from across California, suggesting that more data are needed to validate and refine bark thickness equations within existing fire effects models.
\end{abstract}

\section{Introduction}

There is interest in predicting fire-caused tree mortality in places where prescribed fire or wildfires are common [14]. Heat from flames or smoldering duff at a tree's base can kill trees, especially those with thinner bark [5-8]. Speciesspecific bark thickness equations are central to fire effects models such as FOFEM (First Order Fire Effects Model) $[9,10]$ and FFE-FVS (Fire and Fuels Extension for the Forest Vegetation Simulator) [1, 11, 12].

Tree bark plays a critical role in reducing mortality from fire. Bark protects living cambial tissues from external biotic and abiotic forces [14-17]. Different tree species exhibit distinct strategies in growth and the development of defense features with some allocating proportionally more resources to bark development than others [18-21]. However, there are many factors that can influence the formation of bark and little information exists comparing this trait across geographic gradients $[22,23]$. The properties and function of bark are a result of complex evolutionary strategies by these organisms to perform more efficiently and competitively within their native ranges [21, 22].

Bark is comprised of various tissues covering the stem, branches, and roots of woody plants. It is found outside the secondary xylem and includes the inner living phloem and dead outer tissue [5, 24]. Inner bark is produced directly by the secondary cambium and consists of secondary phloem tissues [18]. Outer bark, also known as the rhytidome, is composed of periderm, cortical, and phloem tissue [25]. Bark plays an important physiological role in protecting trees from the environment and infectious microorganisms as well as containing mechanical injuries $[18,26]$. Bark thickness (BT) is the most important characteristic for cambial protection from fire, more so than other bark properties like density, moisture content, or structure $[14,20,27]$. Trees with thicker bark are more likely to survive wildfire events. Thick bark provides an insulating layer of protection from heat for the underlying vascular tissues which can prevent cambial girdling $[6,28-31]$. 
Standard fire-caused tree mortality models use BT, derived from species-specific BT equations, along with percent crown scorch as predictors of tree mortality $[1,9,11,12]$. However, despite its importance in fire-induced tree mortality modeling, there are few studies assessing BT across a range of species and locations [32]. Studies analyzing external factors influencing BT are limited [32]. Site quality and soil fertility have been considered [33], but site quality cannot be easily altered by forest management. Measures of tree vigor, such as annual radial growth rates, can be associated with reduced likelihood of tree mortality during disturbances such as wildfire [29]. Competition can be reduced to enhance tree vigor but with an unknown influence on BT.

While there are studies correlating BT to tree diameter [34-37], we did not find any that tested for the influence of tree growth and vigor on BT. Therefore, we sought to test whether vigorous rapidly growing trees (in terms of crown ratio or recent growth rate) might allocate more or less resources to bark production. Also unknown is whether BT is an adaptation to fire that differs among areas with different climates and fire regimes. Therefore, we used regression analysis to test for such effects and compared our BT data and best BT models against existing BT models implemented within fire effects models. Our objectives were to

(i) examine how BT relates to measures of tree size [diameter at breast height $(\mathrm{DBH})$ ], recent growth rates (GR), vigor [crown ratio (CR)], and crown position [crown class (CC)];

(ii) quantify BT variation among species along a latitudinal gradient;

(iii) develop BT prediction models and compare their predictions against published BT models for the mixed-conifer forest type.

\section{Materials and Methods}

2.1. Study Sites. Data for the mixed-conifer forest type were collected from Klamath, Tahoe, and Sequoia National Forests and the Stanislaus-Tuolumne Experimental Forest in California. Sampling at these locations provided a latitudinal gradient across the range of mixed-conifer species (Figure 1). Eight species were sampled for BT: white fir (Abies concolor) [ABCO], red fir (Abies magnifica) [ABMA], incensecedar (Calocedrus decurrens) [CADE], lodgepole pine (Pinus contorta) [PICO], Jeffrey pine (Pinus jeffreyi) [PIJE], sugar pine (Pinus lambertiana) [PILA], western white pine (Pinus monticola) [PIMO], and Douglas-fir (Pseudotsuga menziesii) [PSME]. Climate and geology varied among the study sites (Table 1). The Klamath National Forest (KNF) is recognized as one of America's most biologically diverse regions [38, 39]. It is situated in a transitional region between hotter and drier areas to the south and colder, wetter climate to the north [40]. Unlike our other study sites, KNF has the Shasta red fir variety (Abies magnifica var. shastensis). The Tahoe National Forest (TNF) data were collected in the Blackwood Creek watershed of the Lake Tahoe Basin Management Unit. This area has a Mediterranean continental climate with warm, dry

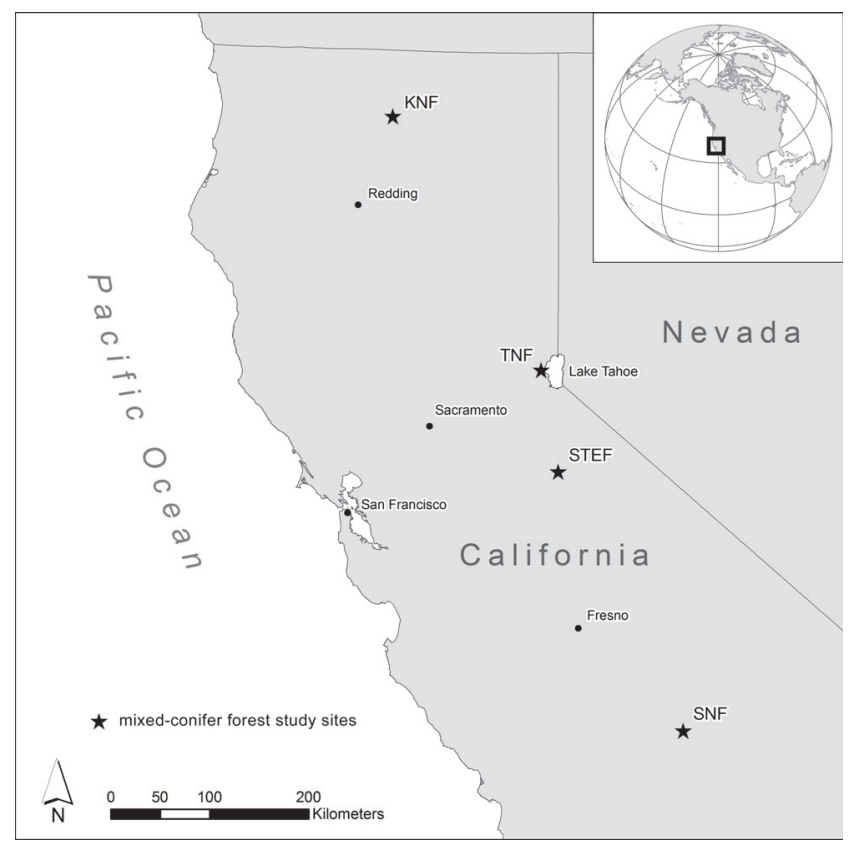

FIGURE 1: Bark thickness sampling in California. Stars show sample locations at Klamath National Forest (KNF), Tahoe National Forest (TNF), Stanislaus-Tuolumne Experimental Forest (STEF), and Sequoia National Forest (SNF). Major cities are shown for reference.

summers and cold winters with most precipitation falling as snow. The Stanislaus-Tuolumne Experimental Forest (STEF) is located near the town of Pinecrest, California. It is a mixedconifer forest of high site quality on the western slope of the Sierra Nevada, at lower elevation than the other two Sierra Nevada sites (TNF and SNF). Climate of the region is characterized by warm, dry summers and cold, wet winters, with over half of annual precipitation falling as snow between December and March. The Sequoia National Forest (SNF) sampling was conducted in the Bull Run Creek watershed which has characteristic expansive areas of exposed rock, particularly at higher elevations. The area experiences warm to hot, dry summers and cool to cold, wet winters. Summer brings occasional thunderstorms but most precipitation is in the form of snow falling from October through April.

2.1.1. Field Data Collection. At KNF, TNF, and SNF, trees were sampled along transects spanning an elevation gradient. Every $100 \mathrm{~m}$ the closest tree was sampled, followed by one tree of each species in understory and overstory positions, giving data for a range of tree sizes and stand densities. Transects were not straight; they climbed and traversed the slope from bottom to top of each watershed, running approximately parallel to the main creek and avoiding road corridors. Trees below five $\mathrm{cm} \mathrm{DBH}$ (diameter at breast height), noticeably unhealthy trees, and malformed trees were not sampled. Bark thickness, recent radial growth, and diameter measurements were taken at a height of $1.37 \mathrm{~m}$ on each sample tree. Total height and live crown base height were also measured to calculate live crown ratio (CR). Crown class was recorded for each sample tree. 
TABLE 1: Description of study sites at Klamath National Forest (KNF), Tahoe National Forest (TNF), Stanislaus-Tuolumne Experimental Forest (STEF), and Sequoia National Forest (SNF). Average temperature is reported as the mean temperature during winter and summer months, respectively. Soil types include parent material (PM). Species sampled: Douglas-fir (PSME), red fir (ABMA), white fir (ABCO), incense-cedar (CADE), sugar pine (PILA), western white pine (PIMO), Jeffrey pine (PIJE), and lodgepole pine (PICO).

\begin{tabular}{|c|c|c|c|c|c|c|}
\hline Site & Location & $\begin{array}{l}\text { Average } \\
\text { temp. } \\
\left({ }^{\circ} \mathrm{C}\right)\end{array}$ & $\begin{array}{l}\text { Annual } \\
\text { precip. } \\
(\mathrm{mm})\end{array}$ & $\begin{array}{l}\text { Soil type and } \\
\text { parent materials }\end{array}$ & $\begin{array}{l}\text { Species sampled and sample size } \\
\text { (number of trees) }\end{array}$ & $\begin{array}{l}\text { Elevation } \\
\text { range of } \\
\text { sampling } \\
(\mathrm{m})\end{array}$ \\
\hline $\mathrm{KNF}$ & $\begin{array}{c}41.5003^{\circ} \mathrm{N} \\
123.3333^{\circ} \mathrm{W}\end{array}$ & $24-41$ & 559 & $\begin{array}{l}\text { Gravely clay loam } \\
\text { PM: basic igneous, } \\
\text { metamorphic, and altered } \\
\text { sedimentary rocks }\end{array}$ & $\begin{array}{l}\text { ABCO (53), ABMA (48), CADE } \\
\text { (29), PILA (17), PIMO (6), PSME } \\
(30)\end{array}$ & $1508-1868$ \\
\hline TNF & $\begin{array}{c}39.5625^{\circ} \mathrm{N} \\
120.5625^{\circ} \mathrm{W}\end{array}$ & $6-23$ & 1,397 & $\begin{array}{l}\text { Gravely loam } \\
\text { PM: andesite and volcanic } \\
\text { rock }\end{array}$ & $\begin{array}{l}\text { ABCO (39), ABMA (53), PICO } \\
(29), \text { PIJE (20), PIMO (23) }\end{array}$ & $2013-2369$ \\
\hline STEF & $\begin{array}{l}38.1677^{\circ} \mathrm{N} \\
120.0^{\circ} \mathrm{W}\end{array}$ & $0-17$ & 940 & $\begin{array}{l}\text { Sandy to fine sandy loam } \\
\text { PM: granite and diorite }\end{array}$ & $\begin{array}{l}\text { ABCO (365), CADE (221), PIJE } \\
\text { (51), PILA (189) }\end{array}$ & $1820-1948$ \\
\hline SNF & $\begin{array}{c}37.4167^{\circ} \mathrm{N} \\
119.1667^{\circ} \mathrm{W}\end{array}$ & $7-26$ & 660 & $\begin{array}{l}\text { Sandy clay loam } \\
\text { PM: sedimentary, granite, } \\
\text { and granodiorite }\end{array}$ & $\begin{array}{l}\text { ABCO (40), ABMA (37), CADE } \\
(16), \text { PIJE (10), PILA (6) }\end{array}$ & $2066-2499$ \\
\hline
\end{tabular}

Two BT measurements were taken using a handheld Swedish bark gauge at approximately 90 degrees apart around the tree circumference. Bark thickness was measured from the wood surface to the contour of the diameter tape wrapped snugly around the tree [41]. One shallow increment core was collected at the site of BT measurements. The collective width of the most recent five complete rings measured to the nearest $0.1 \mathrm{~mm}$ gave tree growth (GR) in terms of a fiveyear periodic average annual radial increment (although the series was not crossdated so it is possible that increment was over/underestimated due to missing/false tree rings).

We obtained independently collected data for BT and $\mathrm{DBH}$ in $\mathrm{ABCO}, \mathrm{CADE}, \mathrm{PIJE}$, and PILA at the STEF site in the central Sierra Nevada (Andrew Slack, Humboldt State University, personal communication). Here, sample trees were nearest neighbors of individual PILA trees randomly selected throughout the forest for a different study. Growth and crown ratio were not measured at STEF.

2.2. Analysis. We used multiple linear regression and nonlinear regression to model BT for each species at three study sites with growth and crown ratio data (KNF, TNF, and $\mathrm{SNF}$ ). Individual variables were either square root- or logtransformed to reduce skewness in data distributions. We compared regression models with and without candidate predictor variables representing tree size $(\mathrm{DBH})$, growth $(\mathrm{GR}$, converted from radial increment to a basal area increment), and tree vigor (CR). The $y$-intercept was forced through the origin because a tree with zero DBH is exactly $1.37 \mathrm{~m}$ tall and essentially has zero BT at that height (the tip) but begins to develop bark at breast height as the tree grows taller. We used a second-order correction for Akaike information criterion (AICc) in model selection as this takes into account sample size by increasing the relative penalty for model complexity with small data sets [42]. Models with delta AICc $<2$ were treated as similar, among which the most parsimonious model was favored. We also calculated average BT prediction error ( $\mathrm{mm}$ ) in terms of root-mean-square error (RMSE) as an indicator of model performance.

The large sample size for ABCO and ABMA allowed for investigation of geographic location (north, central, and southern latitudes), as well as crown class (dominant, codominant, intermediate, and suppressed) influence on BT. Dummy variables were included in nonlinear regressions to test for differences in BT between categorical variables of site and crown class.

We examined performance of existing, widely used BT models by comparing predictions from these BT models against our California BT models and data. Specifically, we compared our California BT data against predictions from diameter inside bark equations for $\mathrm{ABCO}$, CADE, PILA, and PSME in southwest Oregon [13] as well as those embedded in the Fire and Fuels Extension (FFE) of the Forest Vegetation Simulator (FVS) $[11,12]$. We did not validate another commonly used fire mortality model, FOFEM (First Order Fire Effects Model) version 6.3.1, because the same bark thickness equations were also embedded in the Fire and Fuels Extension (FFE) version 2.0. Prediction errors were calculated in percent terms for each tree in our dataset (percent error $=100 \times($ predicted-actual $) /$ predicted $)$. We used $R$ [43] and SPSS [44] to analyze data.

\section{Results and Discussion}

Sample trees covered a broad range of tree sizes, crown ratio, and growth (Supplementary File, Table S1, in Supplementary Material available online at http://dx.doi.org/10.1155/ 2016/1864039). Sample size across the KNF, TNF, and SNF sites differed among species. ABCO and ABMA were encountered most frequently along the sample transects. The independent dataset from STEF added records for four species, including very large PILA, as well as CADE, PIJE, and ABCO (Supplementary File, Table S2). 
TABLE 2: Comparison of bark thickness (BT; $\mathrm{mm}$ ) as a function of DBH (cm) across latitudinal gradient (north, central, south) and among crown classes (dominant, codominant, intermediate, and suppressed) for red fir (ABMA) and white fir (ABCO) at Klamath National Forest (KNF), Tahoe National Forest (TNF), and Sequoia National Forest (SNF). Coefficients and fit statistics for region and crown class dummy variable $(d)$ in nonlinear regression.

\begin{tabular}{|c|c|c|c|c|c|}
\hline \multirow{2}{*}{ Species } & \multirow{2}{*}{ Region/crown class } & \multirow{2}{*}{ Coefficient $(d)$} & \multirow{2}{*}{ s.e. } & \multicolumn{2}{|c|}{ Appr. 95\% confidence limits } \\
\hline & & & & Lower & Upper \\
\hline \multicolumn{6}{|l|}{$\operatorname{ABMA}(n=138)$} \\
\hline \multirow{3}{*}{$\sqrt{\mathrm{BT}}=0.900 \sqrt{\mathrm{DBH}}^{d}(\mathrm{RMSE}=6.22 \mathrm{~mm})$} & North (KNF) & 0.875 & 0.032 & 0.812 & 0.938 \\
\hline & Central (TNF) & 0.941 & 0.031 & 0.880 & 1.003 \\
\hline & South (SNF) & 0.917 & 0.030 & 0.858 & 0.976 \\
\hline \multirow{4}{*}{$\sqrt{\mathrm{BT}}=0.801 \sqrt{\mathrm{DBH}}^{d}(\mathrm{RMSE}=6.75 \mathrm{~mm})$} & Dominant & 0.964 & 0.042 & 0.881 & 1.047 \\
\hline & Codominant & 0.973 & 0.051 & 0.872 & 1.074 \\
\hline & Intermediate & 1.012 & 0.059 & 0.896 & 1.128 \\
\hline & Suppressed & 1.041 & 0.068 & 0.906 & 1.176 \\
\hline \multicolumn{6}{|l|}{$\operatorname{ABCO}(n=132)$} \\
\hline \multirow{3}{*}{$\sqrt{\mathrm{BT}}=1.005 \sqrt{\mathrm{DBH}}^{d}(\mathrm{RMSE}=6.15 \mathrm{~mm})$} & North (KNF) & 0.856 & 0.056 & 0.745 & 0.967 \\
\hline & Central (TNF) & 0.888 & 0.029 & 0.831 & 0.945 \\
\hline & South (SNF) & 0.865 & 0.028 & 0.810 & 0.921 \\
\hline \multirow{4}{*}{$\sqrt{\mathrm{BT}}=0.878 \sqrt{\mathrm{DBH}}^{d}(\mathrm{RMSE}=6.20 \mathrm{~mm})$} & Dominant & 0.924 & 0.036 & 0.853 & 0.995 \\
\hline & Codominant & 0.947 & 0.043 & 0.861 & 1.033 \\
\hline & Intermediate & 0.964 & 0.051 & 0.863 & 1.065 \\
\hline & Suppressed & 0.996 & 0.060 & 0.877 & 1.116 \\
\hline
\end{tabular}

There was a positive trend of increasing tree size $(\mathrm{DBH})$ and BT, although the BT of some conifers varied widely for any given tree size. In general, nonlinear relationships best explained our empirical data with the exception of PSME and CADE where simpler linear models were adopted. Incorporating tree vigor (in terms of recent growth, GR) improved model predictions of bark thickness for four mixed-conifer species, ABCO, ABMA, PICO, and PIJE, indicating that faster growth came at the expense of BT (Supplementary Files, Tables S3 and S4). However, in practice the small differences in prediction errors ( $8 \%$ overall average reduction in RMSE; range $4 \%-16 \%$ reduction by species) indicated that including GR as a predictor of BT only gave marginal improvements over the simplified models with only $\mathrm{DBH}$ as a parameter (Supplementary File, Table S3).

We found no significant difference in BT for ABMA or ABCO along the latitude gradient of northern (KNF), central (TNF), and southern (SNF) sample locations. On average, the shastensis variety of ABMA had thinner bark for a given tree size than ABMA along the Sierra Nevada. Bark thickness was slightly but not significantly greater at TNF than further south at SNF (Table 2) where mean GR for ABMA was $3.18 \mathrm{~mm} \mathrm{yr}^{-1}$ (i.e., $31 \%$ faster). ABCO exhibited a similar but less pronounced trend of thicker bark at TNF and thinner bark at KNF but variability in BT at each site prevented detection of significant differences. Variability in BT was greater among ABMA than ABCO sample trees. For a given tree size in ABMA or ABCO, average BT by crown class was ranked as follows: suppressed $>$ intermediate $>$ codominant $>$ dominant; however, these differences were not statistically significant but were consistent with negative coefficients for GR indicating that faster-growing trees had thinner bark (Supplementary File, Table S3). It should be noted that there are several other factors beyond latitudinal variation which could contribute to the observed differences in BT, such as past management and disturbance regimes, as well as variations in climate and site quality between each of the study locations.

Independently collected BT data from STEF exhibited greater BT for a given $\mathrm{DBH}$ than $\mathrm{BT}$ at the three National Forest sites. In comparison with STEF data, predictions from our simple BT-DBH models for the KNF, TNF, and SNF locations (models shown in Supplementary File, Table S3) revealed that predicted $\mathrm{BT}$ was $10.5 \%$ less for $\mathrm{ABCO}, 20.9 \%$ less for CADE, $15.1 \%$ less for PIJE, and 21.2\% less for PILA than the BT data for the STEF site. To increase the geographic range of applicability of our BT-DBH models, we merged the data from KNF, TNF, SNF, and STEF sites and fitted final models to this expanded dataset (Table 3 and Figure 2). The STEF dataset included BT for larger CADE, PIJE, and PILA than the other sites. Our final models indicated that BT among large-sized $(100 \mathrm{~cm} \mathrm{DBH})$ California mixed-conifers was thickest for CADE and thinnest for PIMO and PICO (Figure 3). Modeled averages for BT in sample trees above $150 \mathrm{~cm} \mathrm{DBH}$ ranked PSME > ABCO > PILA. Expected bark thickness (i.e., modeled average) for a $50 \mathrm{~cm} \mathrm{DBH}$ tree fell into three groupings, where CADE, PIJE, and PILA had relatively thick bark, ABCO, PSME, and ABMA had intermediate BT, and PIMO and PICO had relatively thin bark. Our California models can be used to estimate BT 
TABLE 3: Mixed-conifer forest type bark thickness (BT) models for red fir (ABMA), lodgepole pine (PICO), western white pine (PIMO), and Douglas-fir (PSME) at three sites: Klamath National Forest (KNF), Tahoe National Forest (TNF), and Sequoia National Forest (SNF), and models for white fir (ABCO), Jeffrey pine (PIJE), sugar pine (PILA), and incense-cedar (CADE) fitted to data from four sites including Stanislaus-Tuolumne Experimental Forest (STEF). Models predict square root of bark thickness in mm, as a function of DBH ( $\mathrm{cm})$.

\begin{tabular}{|c|c|c|c|c|c|c|}
\hline Data & Model & & Coefficient & s.e. & $\operatorname{Pr}>|t|$ & RMSE (mm) \\
\hline $\begin{array}{l}\mathrm{ABCO} \\
(n=497)\end{array}$ & $\sqrt{\mathrm{BT}}=a *{\sqrt{\mathrm{DBH}^{b}}}^{b}$ & $\begin{array}{l}a \\
b\end{array}$ & $\begin{array}{l}1.005 \\
0.888\end{array}$ & $\begin{array}{l}0.031 \\
0.016\end{array}$ & $\begin{array}{l}<0.0001 \\
<0.0001\end{array}$ & 7.46 \\
\hline $\begin{array}{l}\text { ABMA } \\
(n=138)\end{array}$ & $\sqrt{\mathrm{BT}}=a * \sqrt{\mathrm{DBH}}^{b}$ & $\begin{array}{l}a \\
b\end{array}$ & $\begin{array}{l}0.886 \\
0.919\end{array}$ & $\begin{array}{l}0.060 \\
0.034\end{array}$ & $\begin{array}{l}<0.0001 \\
<0.0001\end{array}$ & 6.88 \\
\hline $\begin{array}{l}\text { PIJE } \\
(n=81)\end{array}$ & $\sqrt{\mathrm{BT}}=a * \sqrt{\mathrm{DBH}}^{b}$ & $\begin{array}{l}a \\
b\end{array}$ & $\begin{array}{l}1.298 \\
0.802\end{array}$ & $\begin{array}{l}0.109 \\
0.041\end{array}$ & $\begin{array}{l}<0.0001 \\
<0.0001\end{array}$ & 10.29 \\
\hline $\begin{array}{l}\text { PICO } \\
(n=29)\end{array}$ & $\sqrt{\mathrm{BT}}=a *{\sqrt{\mathrm{DBH}^{b}}}^{b}$ & $\begin{array}{l}a \\
b\end{array}$ & $\begin{array}{l}1.027 \\
0.603\end{array}$ & $\begin{array}{l}0.104 \\
0.057\end{array}$ & $\begin{array}{l}<0.0001 \\
<0.0001\end{array}$ & 1.49 \\
\hline $\begin{array}{l}\text { PILA } \\
(n=212)\end{array}$ & $\sqrt{\mathrm{BT}}=a * \sqrt{\mathrm{DBH}}^{b}$ & $\begin{array}{l}a \\
b\end{array}$ & $\begin{array}{l}1.521 \\
0.718\end{array}$ & $\begin{array}{l}0.116 \\
0.034\end{array}$ & $\begin{array}{l}<0.0001 \\
<0.0001\end{array}$ & 14.50 \\
\hline $\begin{array}{l}\text { PIMO } \\
(n=29)\end{array}$ & $\sqrt{\mathrm{BT}}=a * \sqrt{\mathrm{DBH}}^{b}$ & $\begin{array}{l}a \\
b\end{array}$ & $\begin{array}{l}1.299 \\
0.609\end{array}$ & $\begin{array}{l}0.156 \\
0.059\end{array}$ & $\begin{array}{l}<0.0001 \\
<0.0001\end{array}$ & 4.24 \\
\hline $\begin{array}{l}\text { PSME } \\
(n=30)\end{array}$ & $\sqrt{\mathrm{BT}}=a * \sqrt{\mathrm{DBH}}$ & $a$ & 0.785 & 0.015 & $<0.0001$ & 7.16 \\
\hline $\operatorname{CADE}(n=266)$ & $\sqrt{\mathrm{BT}}=a * \sqrt{\mathrm{DBH}}$ & $a$ & 0.946 & 0.009 & $<0.0001$ & 14.18 \\
\hline
\end{tabular}

TABLE 4: Performance of bark thickness (BT) models in the Fire and Fuels Extension for the Forest Vegetation Simulator (FFE-FVS) [11, 12] and Larsen \& Hann [13] models for BT in Oregon applied to BT and DBH data for California mixed-conifers. Comparing BT data for Klamath National Forest (KNF), Tahoe National Forest (TNF), Stanislaus-Tuolumne Experimental Forest (STEF), and Sequoia National Forest (SNF) in California against FFE-FVS and Oregon BT model predictions in terms of percent difference between predicted BT and actual BT data calculated as $100 \times($ predicted-actual)/predicted. Negative percentage indicates underprediction by the FFE-FVS or Oregon models.

\begin{tabular}{lcc}
\hline Species & FFE-FVS BT models [11, 12] & Oregon BT models [13] \\
\hline White fir (ABCO) & $-47.7 \%$ & $-49.2 \%$ \\
Incense-cedar (CADE) & $-55.2 \%$ & $-14.4 \%$ \\
Jeffrey pine (PIJE) & $-20.1 \%$ & - \\
Sugar pine (PILA) & $-0.5 \%$ & $11.2 \%$ \\
Douglas-fir (PSME) & $6.9 \%$ & $37.2 \%$ \\
Western white pine (PIMO) & $-17.3 \%$ & - \\
Lodgepole pine (PICO) & $-5.4 \%$ & - \\
Red fir (ABMA) & $-53 \%$ & - \\
\hline
\end{tabular}

using forest inventory data and quantify diameter inside bark at breast height. The minimum and maximum DBH for each species define the range of application of BT models (Supplementary File, Tables S1 and S2).

The percent differences between our data and predicted BT from the FFE-FVS [11, 12] or Oregon [13] BT models indicated that these models generally underpredicted BT in California mixed-conifers, most noticeably for $\mathrm{ABCO}$, ABMA, CADE, and PIJE (Table 4, Figure 4). Prediction errors were greatest among smaller trees, where underprediction was common. When compared against California BT data, the FFE-FVS model underpredicted BT for CADE, ABMA, and $\mathrm{ABCO}$ of all sizes. For PICO, PILA, and PIMO trees in California, the FFE-FVS model underpredicted BT for smaller trees and overpredicted BT for larger trees. The Oregon models overpredicted BT for PILA and PSME, especially among larger PILA and smaller PSME trees (Figure 4).

Underpredicted bark thickness for most species suggested that the FFE-FVS fire effects model may overestimate fire severity in California. This finding is consistent with validation of the postfire tree mortality models in Hood et al. [1] where mortality was overpredicted for many of the same species that we studied. The models for conifers in Oregon indicated that bark was $49 \%$ thinner in Abies concolor and $37 \%$ thicker in Pseudotsuga menziesii than our sample from across California. These important differences and subtler differences according to location and growth rate suggested that more BT data are needed to validate and, if needed, refine equations within existing fire effects models or develop local or regional model variants. Overall, our findings suggest that further study and revision of BT models implemented within fire models are warranted for mixed-conifer forests in California.

\section{Conclusion}

Bark thickness correlated with DBH but varied among conifer species. Our modeling indicated that, among $50 \mathrm{~cm} \mathrm{DBH}$ 

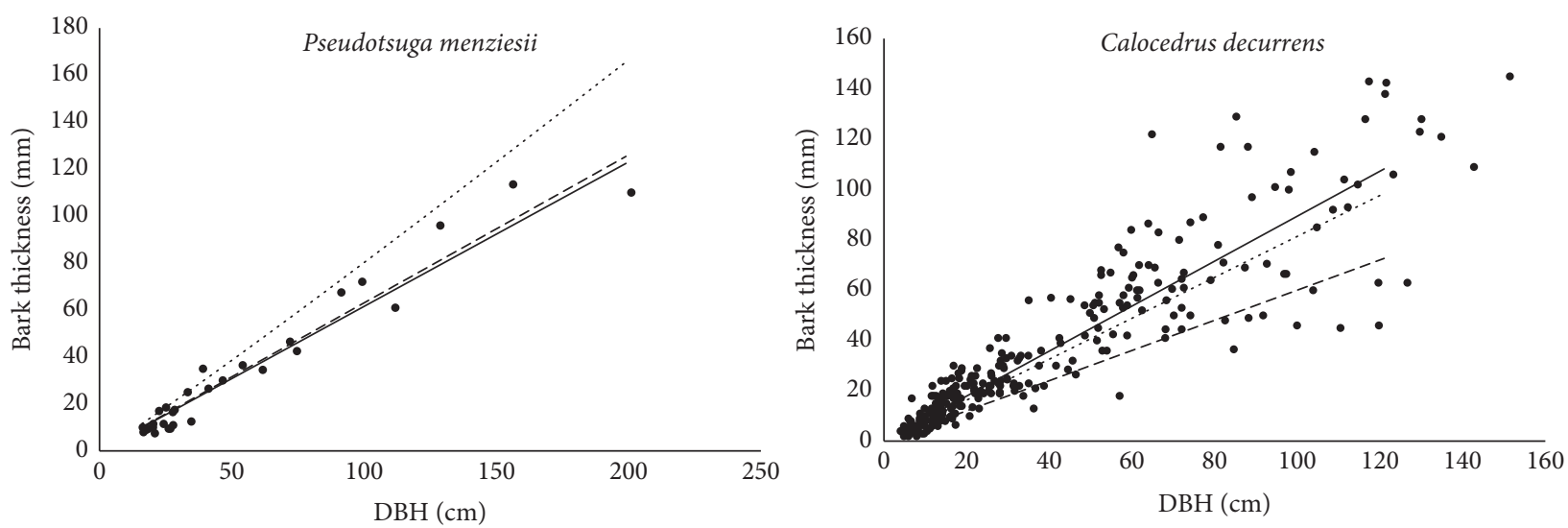

- Actual values

- Predicted values

- - FFE (FVS)

..... Larsen \& Hann

- Actual values

- Predicted values

- - FFE (FVS)

..... Larsen \& Hann
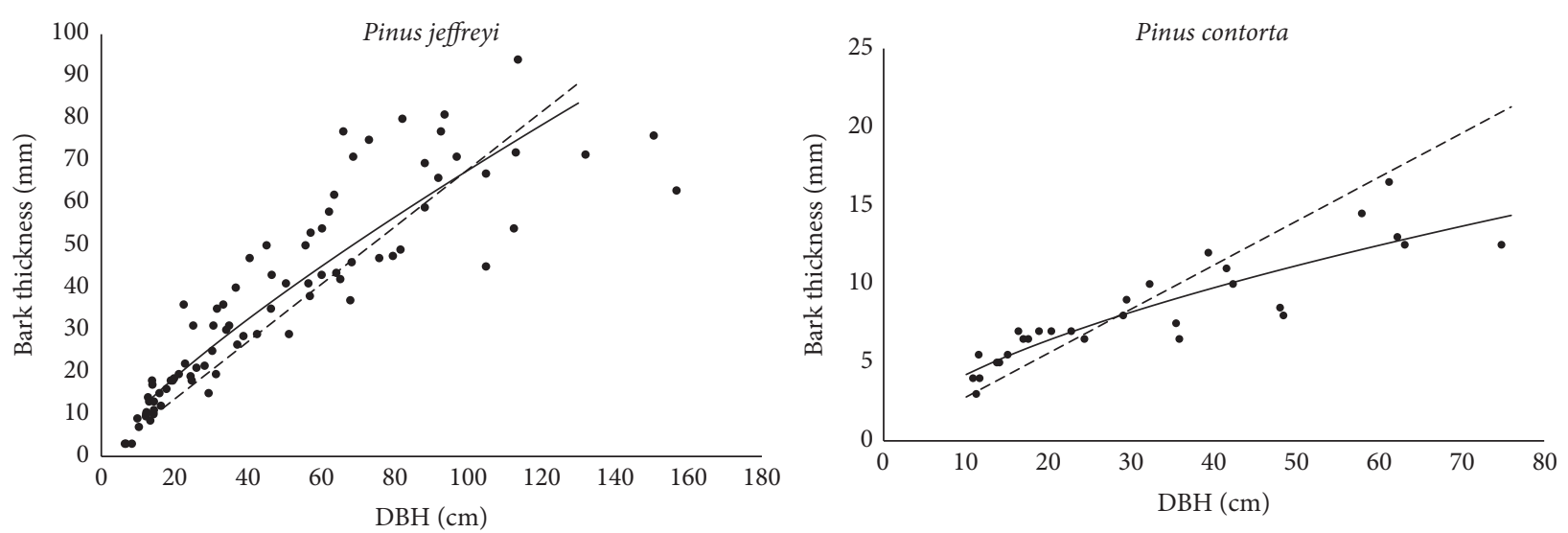

- Actual values

_ Predicted values

- Actual values

- Predicted values

- - - FFE (FVS)

- - FFE (FVS)
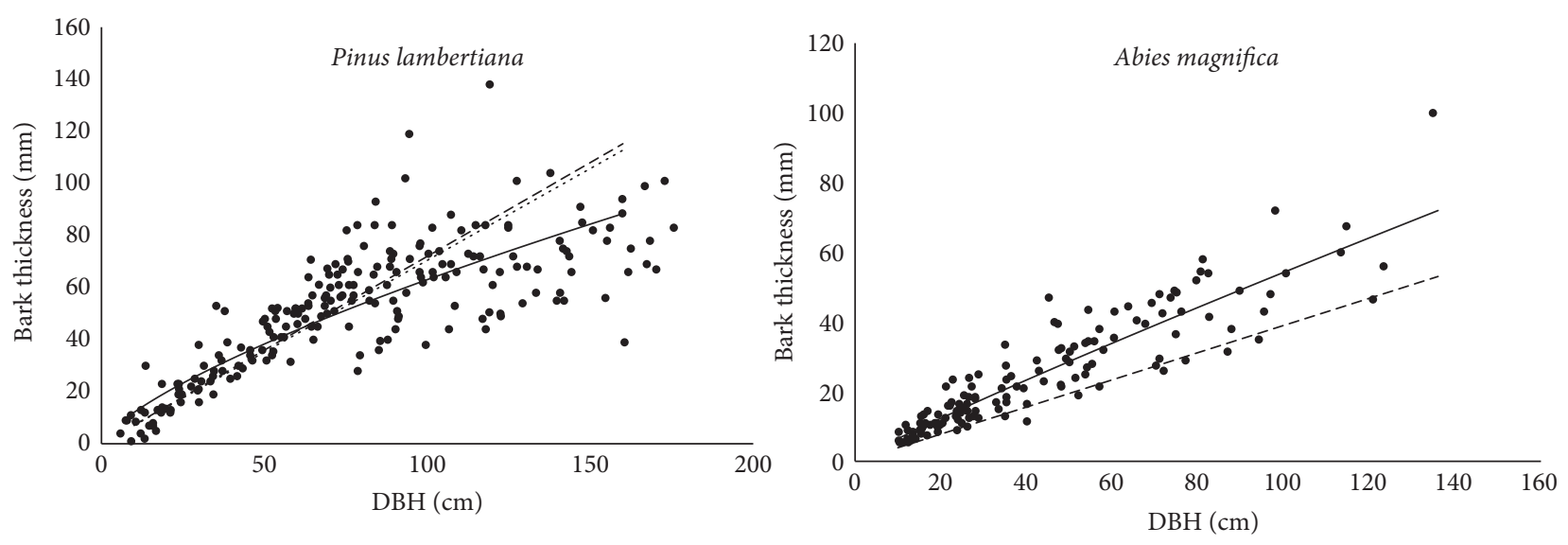

- Actual values

_ Predicted values

- - - FFE (FVS)

Larsen \& Hann

- Actual values

_ Predicted values

- - - FFE (FVS)

Figure 2: Continued. 

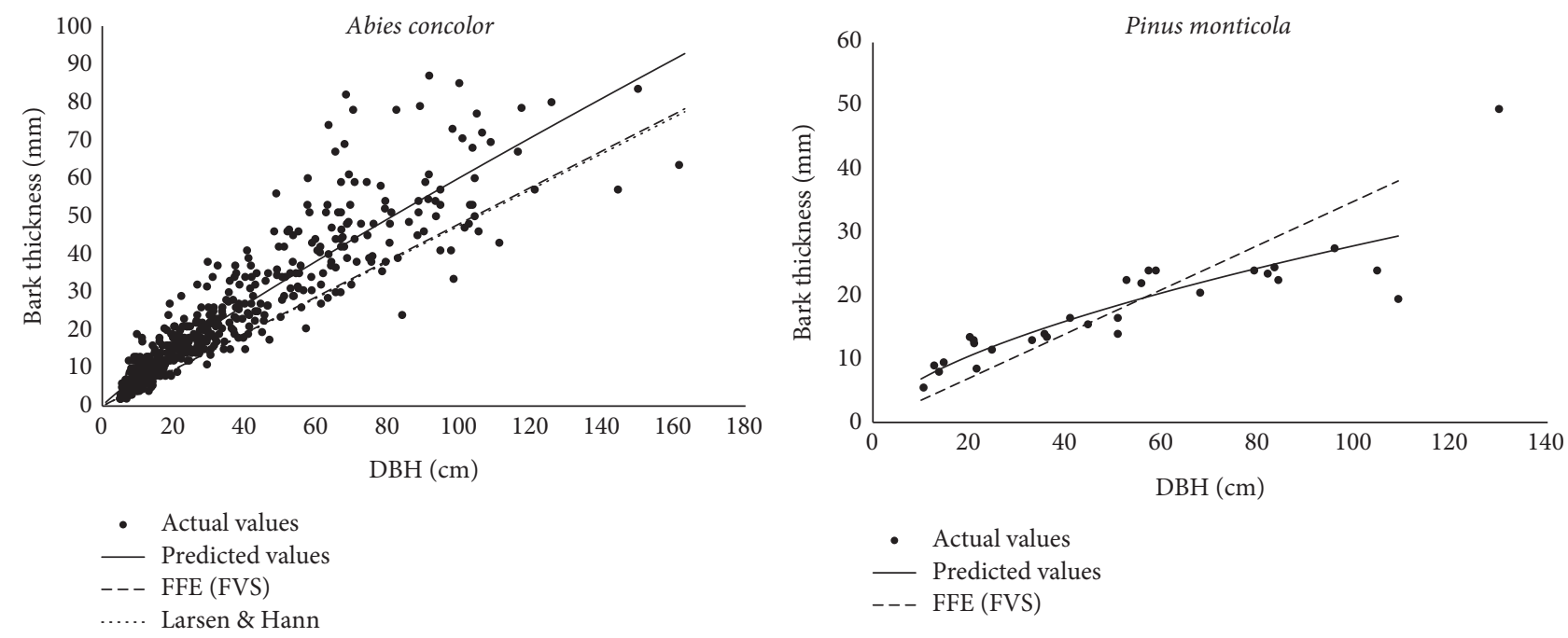

Figure 2: Bark thickness data and models (predicted values) for eight species within the mixed-conifer forests of California. Data were collected across a latitudinal gradient: north (Klamath National Forest), central (Tahoe National Forest and Stanislaus-Tuolumne Experimental Forest), and south (Sequoia National Forest). Dashed lines denote predictions from Fire and Fuels Extension for the Forest Vegetation Simulator (FFE-FVS) [11, 12] or Larsen \& Hann [13] models for BT in Oregon. Note scale differences in $x$ - and $y$-axes for each species.

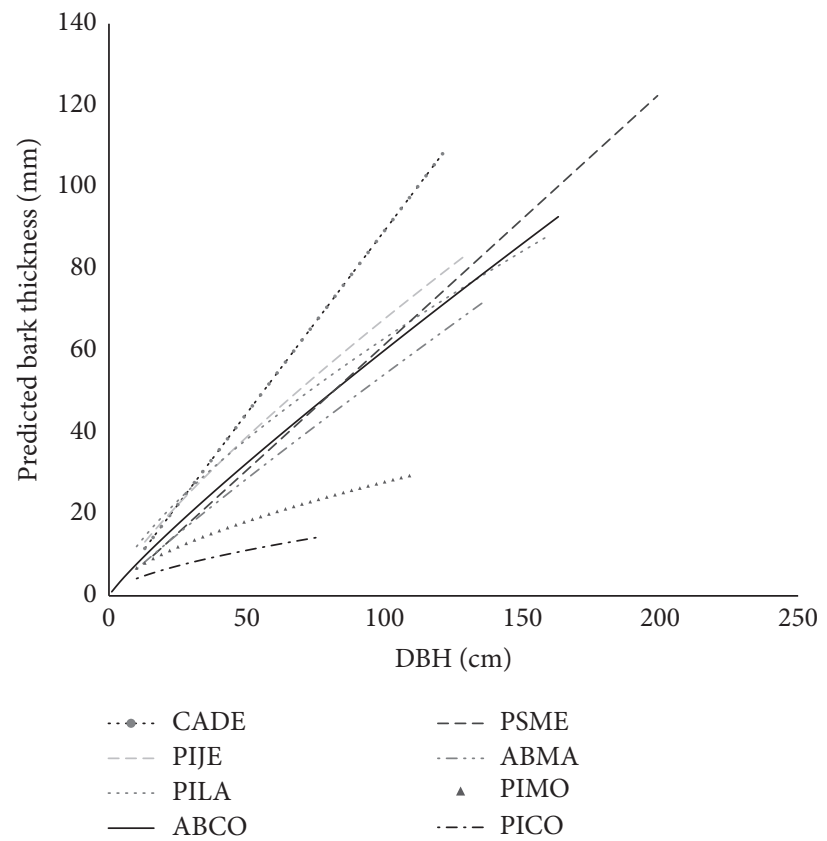

FIGURE 3: Comparing California mixed-conifer forest bark thickness model predictions for eight conifer species at Klamath National Forest (KNF), Tahoe National Forest (TNF), Stanislaus-Tuolumne Experimental Forest (STEF), and Sequoia National Forest (SNF) in California. Species (and codes): Douglas-fir (PSME), red fir (ABMA), white fir (ABCO), incense-cedar (CADE), sugar pine (PILA), western white pine (PIMO), Jeffrey pine (PIJE), and lodgepole pine (PICO).

conifers, $\mathrm{BT}$ ranked $\mathrm{CADE}>\mathrm{PIJE}>\mathrm{PILA}>\mathrm{ABCO}>$ PSME > ABMA > PIMO > PICO. We did not detect regional differences in $\mathrm{BT}$ nor differences between crown class and only slight differences according to recent tree radial growth. These findings suggest that our linear and nonlinear models of BT-DBH have general application within California. We failed to find reasonable agreement between our newly developed BT model predictions and most existing BT models currently used to model fire-induced mortality in the mixed-conifer forest type in California.

\section{Competing Interests}

The authors declare that they have no competing interests. 

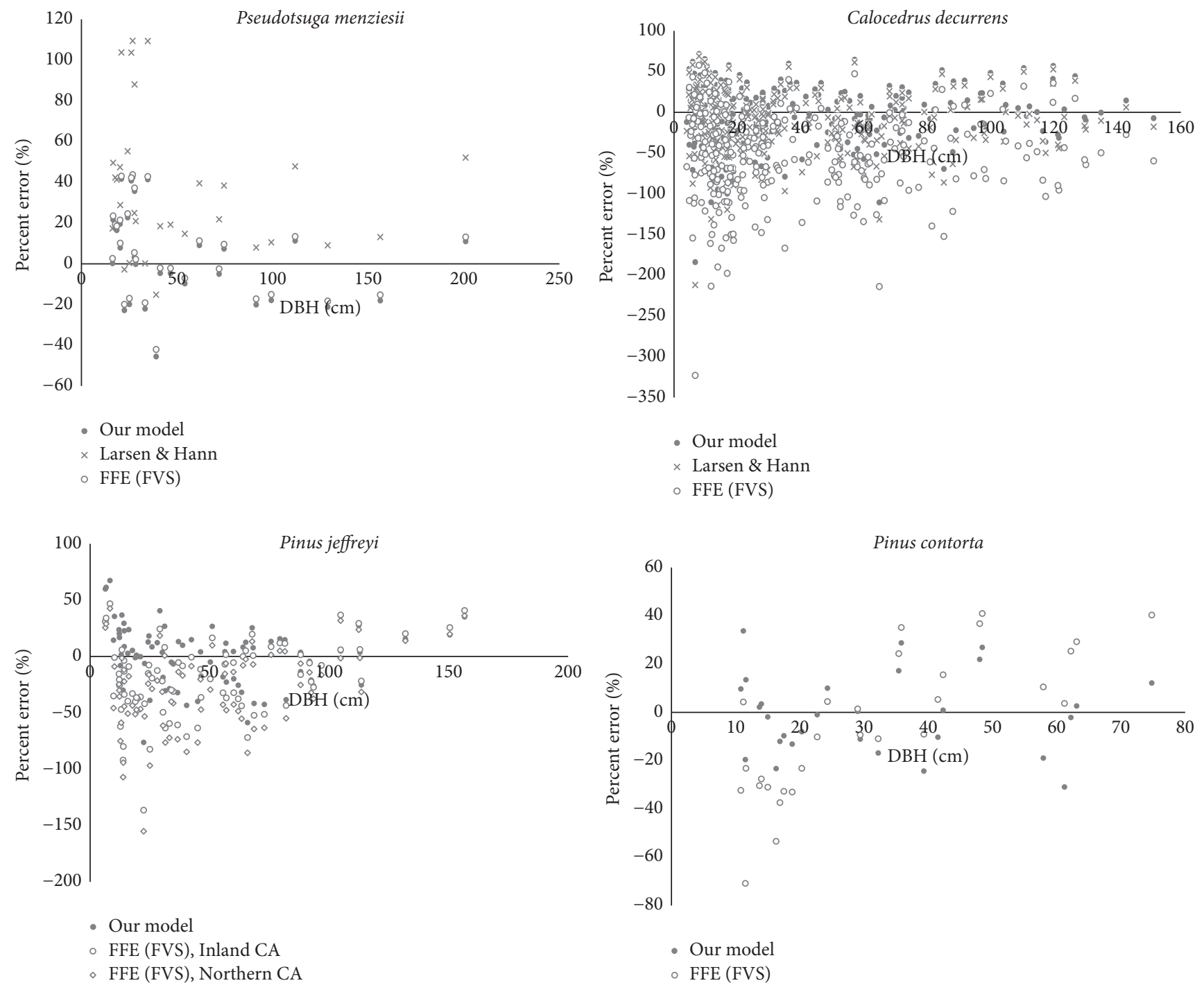

FFE (FVS), Inland CA

- Our model

- FFE (FVS)
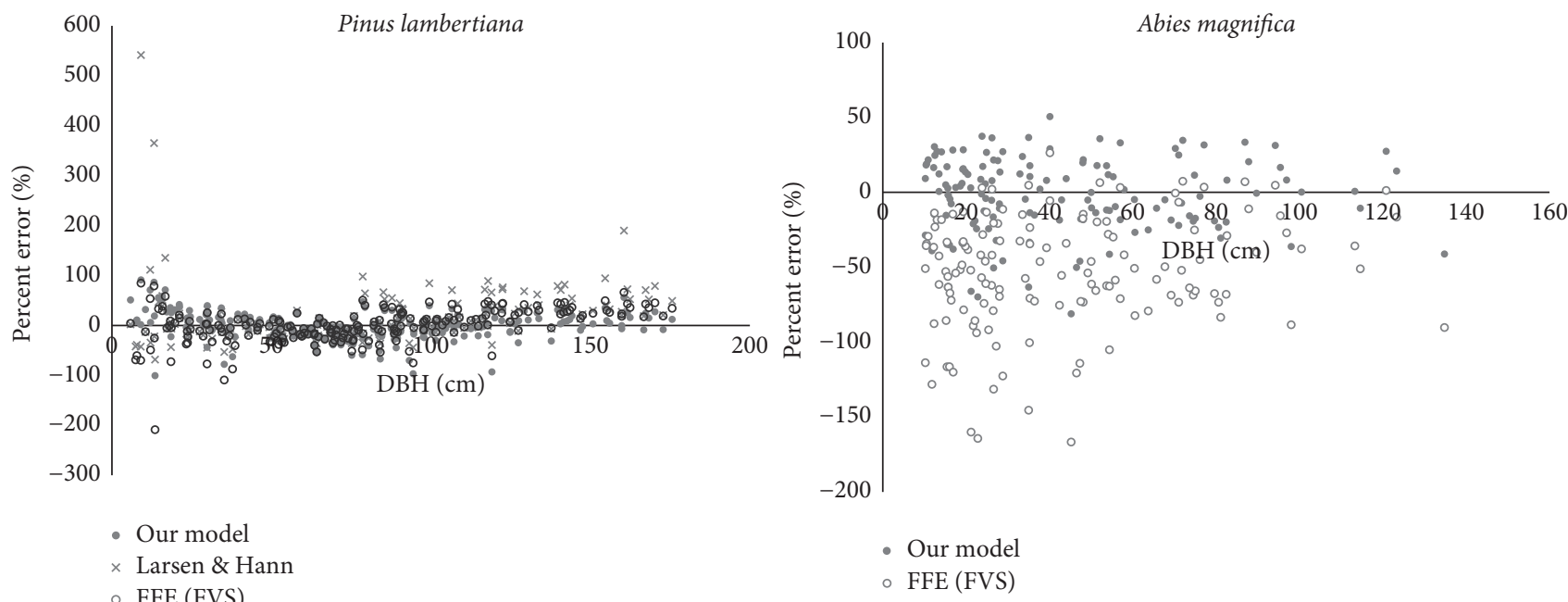

FIgure 4: Continued. 

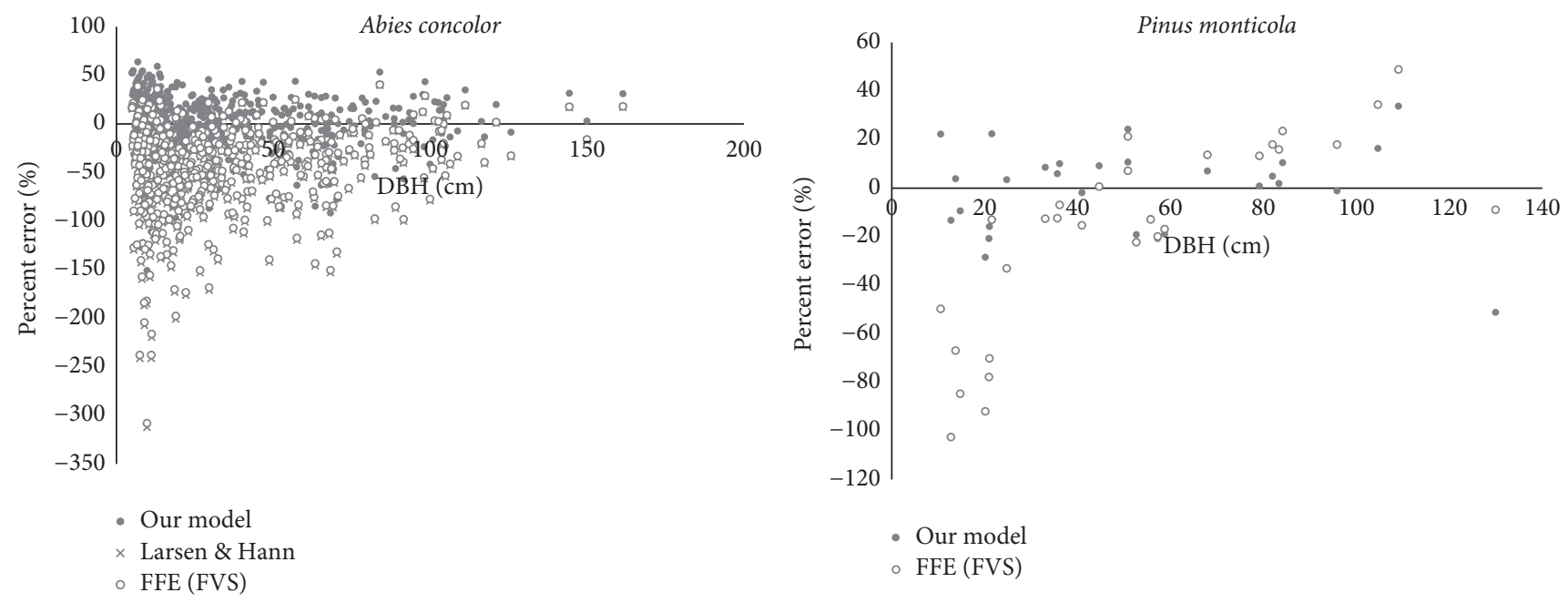

FIGURE 4: Bark thickness model prediction errors according to tree size (DBH) for eight species within the mixed-conifer forests of California. Prediction errors calculated in percent terms for our California models, for FFE-FVS (Fire and Fuels Extension for the Forest Vegetation Simulator) [11, 12], and for the Larsen \& Hann [13] bark thickness models for Oregon, where percent error is the difference between predicted $\mathrm{BT}$ and actual BT data calculated as $100 \times$ (predicted-actual)/predicted.

\section{Authors' Contributions}

NEZ-K summarized and analyzed data and prepared figures. CWA assisted with data summary and performed validations. J-PB designed sampling, assisted with data analysis, and obtained funding. JPK assisted with data summary and validation. All authors contributed to writing of the manuscript.

\section{Acknowledgments}

Andrew Slack provided the independent bark thickness dataset and valuable advice. Scott Burdette collected field data. This work was supported in part by the USDA National Institute of Food and Agriculture, McIntire Stennis Cooperative Research Program.

\section{References}

[1] S. M. Hood, C. W. McHugh, K. C. Ryan, E. Reinhardt, and S. L. Smith, "Evaluation of a post-fire tree mortality model for western USA conifers," International Journal of Wildland Fire, vol. 16, no. 6, pp. 679-689, 2007.

[2] C. Hull Sieg, J. D. McMillin, J. F. Fowler et al., "Best predictors for postfire mortality of ponderosa pine trees in the Intermountain West," Forest Science, vol. 52, no. 6, pp. 718-728, 2006.

[3] J. L. Jones, B. W. Webb, B. W. Butler et al., "Prediction and measurement of thermally induced cambial tissue necrosis in tree stems," International Journal of Wildland Fire, vol. 15, no. 1, pp. 3-17, 2006.

[4] P. E. Dennison, S. C. Brewer, J. D. Arnold, and M. A. Moritz, "Large wildfire trends in the western United States, 1984-2011," Geophysical Research Letters, vol. 41, no. 8, pp. 2928-2933, 2014.

[5] K. W. Spalt and W. E. Reifsnyder, Bark Characteristics and Fire Resistance: A Literature Survey, Southern Forest Experiment Station, USDA Forest Service in cooperation with School of Forestry, Yale University, New Haven, Conn, USA, 1962.
[6] S. T. Michaletz and E. A. Johnson, "How forest fires kill trees: a review of the fundamental biophysical processes," Scandinavian Journal of Forest Research, vol. 22, no. 6, pp. 500-515, 2007.

[7] J. M. Varner, F. E. Putz, J. J. O’Brien, J. K. Hiers, R. J. Mitchell, and D. R. Gordon, "Post-fire tree stress and growth following smoldering duff fires," Forest Ecology and Management, vol. 258, no. 11, pp. 2467-2474, 2009.

[8] D. H. Hammond, J. M. Varner, J. S. Kush, and Z. Fan, "Contrasting sapling bark allocation of five southeastern USA hardwood tree species in a fire prone ecosystem," Ecosphere, vol. 6, no. 7, pp. 1-13, 2015.

[9] E. D. Reinhardt, R. E. Keane, and J. K. Brown, "First Order Fire Effects Model: FOFEM 4.0, User's Guide,” Tech. Rep. INT-GTR344, USDA Forest Service, Ogden, Utah, 1997.

[10] D. C. Lutes and R. E. Keane, First Order Fire Effects Model: FOFEM 6.3, User's Guide, USDA Forest Service, Missoula, Mont, USA, 2016.

[11] E. D. Reinhardt, N. L. Crookston, S. J. Beukema et al., "The fire and fuels extension to the forest vegetation simulator," Tech. Rep. RMRS-GTR-116, USDA Forest Service, Fort Collins, Colo, USA, 2003.

[12] E. D. Reinhardt, N. L. Crookston, S. J. Beukema et al., "Addendum to the fire and fuels extension to the forest vegetation simulator," Tech. Rep. RMRS-GTR-116, UDA Forest Service, Fort Collins, Colo, USA, 2009.

[13] D. R. Larsen and D. W. Hann, Equations for Predicting Diameter and Squared Diameter Inside Bark at Breast Height for Six Major Conifers of Southwest Oregon, Oregon State University College of Forestry, Corvallis, Ore, USA, 1985.

[14] B. Odhiambo, M. Meincken, and T. Seifert, "The protective role of bark against fire damage: a comparative study on selected introduced and indigenous tree species in the Western Cape, South Africa," Trees, vol. 28, no. 2, pp. 555-565, 2014.

[15] I. Roth, Structural Patterns of Tropical Barks, Schweizerbart Borntraeger, Stuttgart, Germany, 1981.

[16] J. L. Jones, B. W. Webb, B. W. Butler et al., "Prediction and measurement of thermally induced cambial tissue necrosis in 
tree stems," International Journal of Wildland Fire, vol. 15, no. 1, pp. 3-17, 2006.

[17] R. L. Edmonds, J. K. Agee, and R. I. Gara, Forest Health and Protection, Waveland Press, Long Grove, Ill, USA, 2011.

[18] A. R. Biggs, W. Merrill, and D. D. Davis, "Discussion: response of bark tissues to injury and infection," Canadian Journal of Forest Research, vol. 14, no. 3, pp. 351-356, 1984.

[19] J. F. Jackson, D. C. Adams, and U. B. Jackson, "Allometry of constitutive defense: a model and a comparative test with tree bark and fire regime," The American Naturalist, vol. 153, no. 6, pp. 614-632, 1999.

[20] P. van Mantgem and M. Schwartz, "Bark heat resistance of small trees in Californian mixed conifer forests: testing some model assumptions," Forest Ecology and Management, vol. 178, no. 3, pp. 341-352, 2003.

[21] D. W. Schwilk, M. S. Gaetani, and H. M. Poulos, "Oak bark allometry and fire survival strategies in the Chihuahuan Desert Sky Islands, Texas, USA," PLoS ONE, vol. 8, no. 11, Article ID e79285, 2013.

[22] J. G. Pausas, "Bark thickness and fire regime," Functional Ecology, vol. 29, no. 3, pp. 315-327, 2015.

[23] J. Laasasenaho, T. Melkas, and S. Aldén, "Modelling bark thickness of Picea abies with taper curves," Forest Ecology and Management, vol. 206, no. 1-3, pp. 35-47, 2005.

[24] S. G. Pallardy, Physiology of Woody Plants, Elsevier, Boston, Mass, USA, 2008.

[25] W. C. Dickison, Integrative Plant Anatomy, Academic Press, San Diego, Calif, USA, 2000.

[26] V. R. Franceschi, P. Krokene, E. Christiansen, and T. Krekling, "Anatomical and chemical defenses of conifer bark against bark beetles and other pests," New Phytologist, vol. 167, no. 2, pp. 353376, 2005.

[27] A. Wesolowski, M. A. Adams, and S. Pfautsch, "Insulation capacity of three bark types of temperate Eucalyptus species," Forest Ecology and Management, vol. 313, pp. 224-232, 2014.

[28] J. Gignoux, J. Clobert, and J.-C. Menaut, "Alternative fire resistance strategies in savanna trees," Oecologia, vol. 110, no. 4, pp. 576-583, 1997.

[29] P. J. van Mantgem, N. L. Stephenson, L. S. Mutch, V. G. Johnson, A. M. Esperanza, and D. J. Parsons, "Growth rate predicts mortality of Abies concolor in both burned and unburned stands," Canadian Journal of Forest Research, vol. 33, no. 6, pp. 1029-1038, 2003.

[30] W. A. Hoffmann, R. Adasme, M. Haridasan et al., "Tree topkill, not mortality, governs the dynamics of savanna-forest boundaries under frequent fire in central Brazil," Ecology, vol. 90, no. 5, pp. 1326-1337, 2009.

[31] J. J. Midgley, M. J. Lawes, and S. Chamaillé-Jammes, "Savanna woody plant dynamics: the role of fire and herbivory, separately and synergistically," Australian Journal of Botany, vol. 58, no. 1, pp. 1-11, 2010.

[32] C. E. T. Paine, C. Stahl, E. A. Courtois, S. Patiño, C. Sarmiento, and C. Baraloto, "Functional explanations for variation in bark thickness in tropical rain forest trees," Functional Ecology, vol. 24, no. 6, pp. 1202-1210, 2010.

[33] K. L. Dolph, "Nonlinear equations for predicting diameter inside bark at breast height for young-growth red fir in California and southern Oregon," Res. Note. PSW-RN-409, USDA Forest Service, Berkeley, Calif, USA, 1989.

[34] G. S. Biging, "Taper equations for second-growth mixed conifers of Northern California," Forest Science, vol. 30, no. 4, pp. 1103-1117, 1984.
[35] E. L. Amidon, "A general taper functional form to predict bole volume for five mixed-conifer species in California," Forest Science, vol. 30, no. 1, pp. 166-171, 1984.

[36] K. C. Ryan and E. D. Reinhardt, "Predicting postfire mortality of seven western conifers," Canadian Journal of Forest Research, vol. 18, no. 10, pp. 1291-1297, 1988.

[37] G. E. Hengst and J. O. Dawson, "Bark properties and fire resistance of selected tree species from the central hardwood region of North America," Canadian Journal of Forest Research, vol. 24, no. 4, pp. 688-696, 1994.

[38] D. A. DellaSala, S. B. Reid, T. J. Frest, J. R. Strittholt, and D. M. Olson, "A global perspective on the biodiversity of the KlamathSiskiyou ecoregion," Natural Areas Journal, vol. 19, no. 1, pp. 300-319, 1999.

[39] S. T. E. Cheng, "Forest service research natural areas in California," Tech. Rep. PSW-GTR-188, USDA Forest Service, Albany, Calif, USA, 2004.

[40] C. G. Parks, S. R. Radosevich, B. A. Endress et al., "Natural and land-use history of the northwest mountain ecoregions (USA) in relation to patterns of plant invasions," Perspectives in Plant Ecology, Evolution and Systematics, vol. 7, no. 3, pp. 137-158, 2005.

[41] C. Mesavage, "Measuring bark thickness," Journal of Forestry, vol. 67, no. 10, pp. 753-754, 1969.

[42] K. P. Burnham and D. R. Anderson, Model Selection and Multimodel Inference: A Practical Information-Theoretic Approach, Springer, New York, NY, USA, 2nd edition, 2002.

[43] R Core Team, R: A Language and Environment for Statistical Computing, R Foundation for Statistical Computing, Vienna, Australia, 2012.

[44] IBM Corporation, SPSS Statistics for Windows, Version 22.0, IBM, Armonk, NY, USA, 2013. 

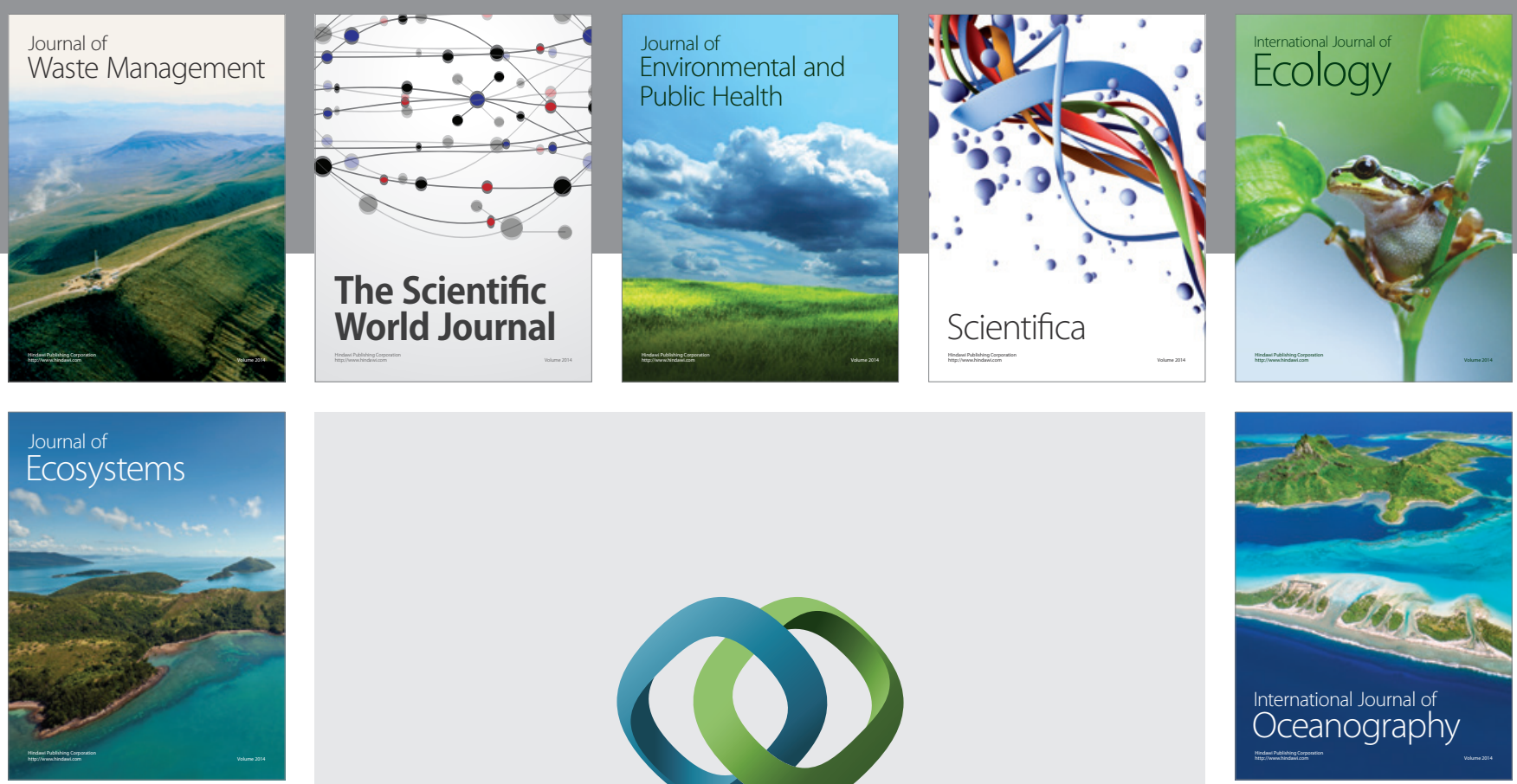

The Scientific World Journal
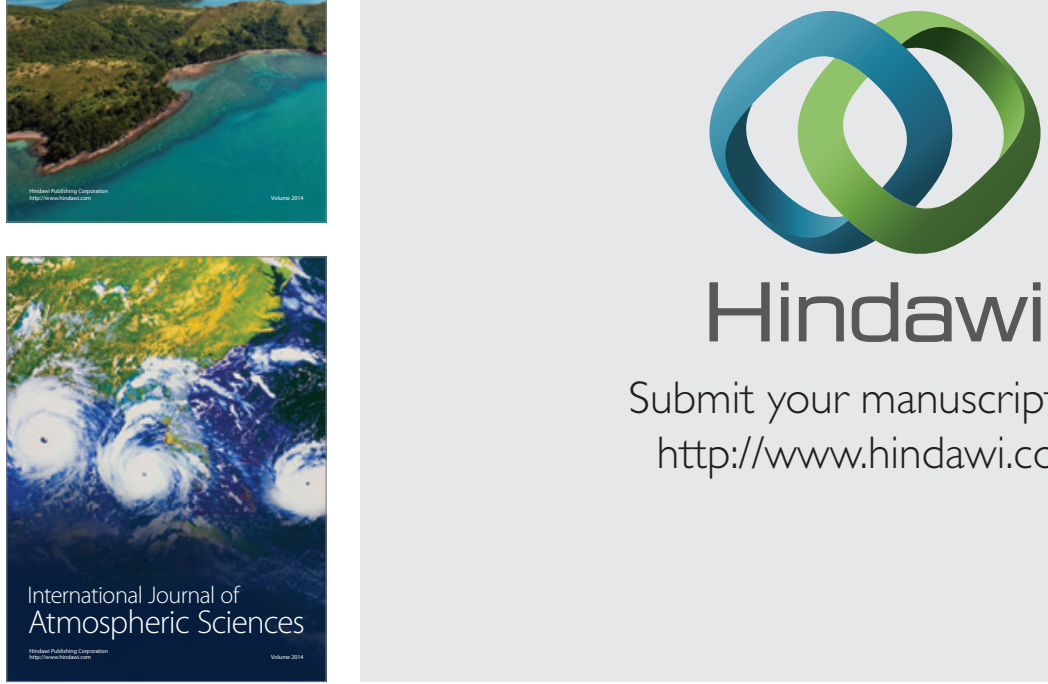

\section{Hindawi}

Submit your manuscripts at

http://www.hindawi.com
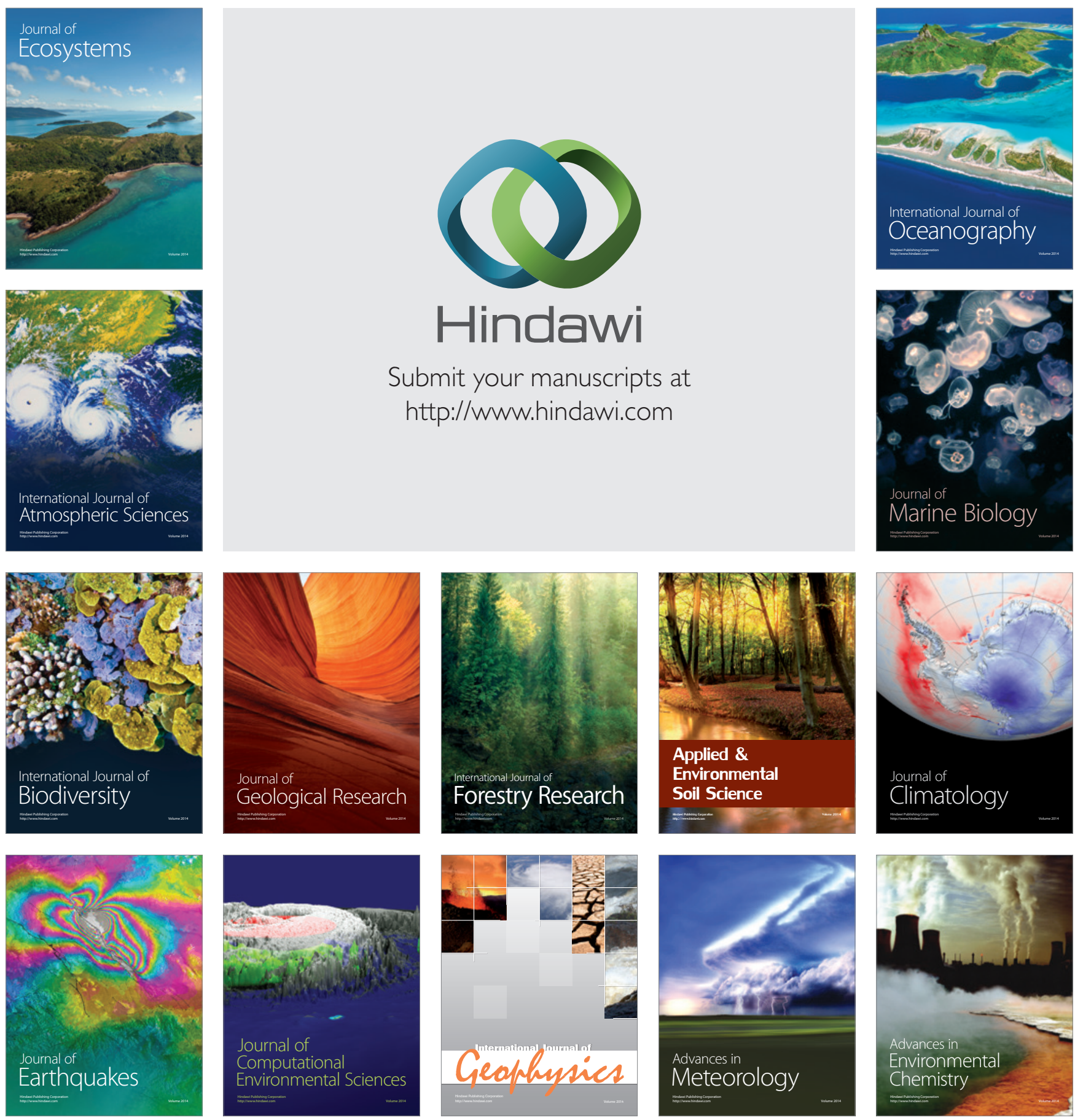